\title{
Effect of Customer Relationship Management on Customer Retention in the Ghanaian Banking Sector
}

\author{
Jerry Jay Kraa1 , Bismark Adanse Bonna ${ }^{1}$, Aquila Hannah ${ }^{1}$, Kankam Boadu ${ }^{1}$ \\ ${ }^{1}$ School of Business, Christian Service University College, P. O. BOX KS 3110, Kumasi, Ghana. \\ Kraaj2@yahoo.com, bismarkbonna@gmail.com \\ aquilahannah@gmail.com, kankamboadu40@yahoo.com
}

\begin{abstract}
The study investigates the effect of customer relationship management on customer retention in the Ghanaian banking sector. The population of the study comprise of customers who used banking services in the Kumasi metropolis in Ghana which is estimated to run into thousands. The study conveniently and purposively sampled 278 of which 278 responses were usable representing $100 \%$ response rate. The study is explanatory and closed ended questionnaires were used collect data. IBM Statistical Package for Social Sciences version 20 was the software used in data analysis. The study used multiple linear regression and correlation for interpretation and testing hypothesis. Cronbach alpha was also used to assessed internal consistency among the variables. The study found customer relationship management to positively and significantly affects customer's retention in the banking industry. The study recommends that customer relationship management should be improved by various banks in order to remain competitive.
\end{abstract}

Keywords: CRM, Organisational structure, Communication channel, Technology availability, Resisting customer complaints, Customer retention.

\section{INTRODUCTION}

Customer relationship management (CRM) and customer satisfaction are strategic decisions taken by firms in both production and operational industry to attract new customers, build a profitable relationship with customers both existing and try to keep customers by meeting their expectations, this helps firms to increase sales of whatever type of product or service they are offering to a particular market; thereby increasing their profits as well (1). Customer relationship consists of managing every aspect of interactions a company has with its customers, including prospecting, sales and service. CRM applications seek to provide insight into and improve the company or customer relationship by combining all these views of customer interaction into one picture (1).

CRM is categorised into four types, namely; strategic CRM, operational CRM, analytical CRM and collaborative CRM. Strategic CRM focuses on winning and retaining profitable customers whilst Operational CRM looks at the automation of customer-facing processes such as selling, marketing and customer service. Analytical CRM is on the intelligent mining of customer-related data but Collaborative CRM applies technology across organizational boundaries (1). Customer satisfaction is a person's judgement of a product's perceived performance in relationship to expectations. If the performance below customer's expectations, the customer is disappointed. If it matches expectations, the customer is satisfied. If it exceeds them, the customer is delighted (2). Customer retention refers to the repeated transactions on a contractual-based relationship with customers, either formal or informal, over a period of time (3).

CRM could bring many benefits to the banking sector, though there are some associated challenges. Such challenges often bring a significant risk of failure; however, the study considers the changes that have emerged in the last decade with regards to customer expectations when patronizing banking products or services. 
Qualitative approaches are used to investigate the overlaps between customer expectations and managers' perceptions of CRM applications. The findings reveal that regardless of all changes, value for money and core products continue to play a critical role in customers' overall satisfaction with banking products or services (4). Customer retention occurs when a customer keeps on buying the same market offering over a long period of time. For products with short purchase cycles, they define customer retention as occurring when 'the customer continues to purchase the product or service over a specified time period'. For products with long purchase cycles, they define customer retention as taking place when the customerindicates the intention to purchase the product or service at the next purchase occasion (5).

Customer retention rate is the percentage of customers at the beginning of the period who still remain customers at the end of the period (6). Payne also suggest that other more complex definitions might be more appropriate in instances where customers make use of more than one business at the same time.

Service organizations need to understand why their customers remain with them and should not assume that when customers remain it is a positive, mindful choice on their part. Customers may stay with a service organization due to any number of (sometimes intangible) ties with it. Some of these are positive, and increase the dedication of customers as with, for example, increased satisfaction. Other links are negative, yet still tie the customer to the service organization: a sales representative, for example, is obliged to stay at a particular hotel every time the customer travels in the area because of an agreement between his or her company and the hotel. Retained customers represent an opportunity to increase profitability as well as loyalty.

\section{LITERATURE REVIEW}

\section{Customer Relationship Management}

Customer relationship management refers to an interactive process for achieving the optimum balance between corporate investments and the satisfaction of customer needs to generate the maximum profit (7). CRM involves; measuring both inputs across all functions including marketing, sales and service costs and outputs in terms of customer revenue, profit and value; acquiring and continuously updating knowledge about customer needs, motivation and behaviour over the lifetime of the relationship; applying customer knowledge to continuously improve performance through a process of learning from successes and failures; integrating the activities of marketing, sales and service to achieve a common goal; the implementation of appropriate systems to support customer knowledge acquisition, sharing and the measurement of CRM effectiveness; constantly flexing the balance between marketing, sales and service inputs against changing customer needs to maximize profits (7).

\section{Organizational Structure}

Successful CRM involves definition of processes, adaptability of employees to new strategy and support of top management, with adequate organizational structure. Successful implementation of CRM concept needs support of top management. Success of bank in today`s competitive environment, depends on ability of top management to adjust business environment where employees manage business processes and implement business relationships with customers. Banks often seek for employees who have appropriate leadership (8). Top management should be actively involved in changes in organization in order to spread positive vision of CRM concept and to support organizational change. An important factor of success in CRM concepts are employees and their commitment to organization. Employees should have appropriate knowledge and techniques which support Customer Relationship Management(8).

\section{Communication Channels}

It is noticed that banks have remarkable investments in information technology. At the time when expansion takes place in banking business, as customers are interested in using new products and services, banks create new services that allow independent use of product with help of modern information solutions. The focus of 
bank's operations is on customers, as each customer represents a separate market segment. Communication between banks and their customers is built ina form of two-way dialogue; hence business success is measured by participation of customers in communication. Banks are developing direct banking channels, which allow customers easier and faster banking operations (9).

Modern banking is done through ATMs, Internet and mobile devices. The use of modern information technology in everyday business, influences on improvement of quality of services; reduces operating costs; decrease cost of investment; creates new products and services; and improves of managerial competence within the bank (9). Continuous development of modern telecommunication media is one of biggest challenges for banking sector. The bank can communicate with each individual customer by: Branches, ATMs ("Automated Teller Machine"), POS ("Point of Sale"), Home Banking, WEB TV-banking, SMS Banking, Internet Banking, Mobile Banking and Social Media (Facebook, Twitter, LinkedIn, YouTube, etc.). Banks should use new communication channels in order to position their products and services. Integration internal process with communication channels contributes to continuous improvement of relationship between banks and customers. The first step in process of integration is identification and assessment of benefits of introducing new communication channel; the bank should select those channels that correspond to particular customer segments or individual customers (9). For example, customers who are in age group of 18 to 45 years prefer communication via Internet, and customers, who are retired, want to contact bank through a Call Center or Branch. When positioning channel communication system with customers, bank should respond on following questions: What customers want from a communication channel? How many customers are willing to pay to get a certain level of service? How effective customers desired services can be provided? What are costs of alternative communication channels for the bank and for the customer?

Depending on response, bank may establish a communication channel that best suits customer. Today, banks can choose between three communication channel strategies (10):

Branch strategy; Branch strategy as a communication channel strategy was very popular thirty years ago. Branch was first point of direct communication with customers.

Internet strategy; Strategy based on Internet involves communication with customers through modern technology, through which customers perform banking transactions independently, with significantly reduced costs.

Distribution Channel strategy; this strategy is the most common practice today, because it allows combination of Branch strategy and Internet strategy. Clients are able to perform most business with bank through modern communication technologies, while for specific jobs, bank staff is available. This strategy allows activities at the lower cost, easier support to customers and increase of sales and profit (9).

\section{CRM Technology}

CRM technology provides better insight into profitability of the customer but, also recognizes customers' habits and needs. CRM technology allows bank to have information about specifics needs of customers, realize personalized approach to each customer, identify the most profitable customers, access customer`s risk profile. CRM technologies are software solutions or CRM tools that support Customer Relationship Management; technology allows gathering necessary information from different sources in order to have a unique picture of each customer in real time (9).

By using CRM tools, employees can quickly make decisions and communicate them to customers in short term. To keep this process successful, bank should use CRM technology that combines two technological components: Data Warehouse, as collection point of data and CRM technology, which enables decision-makers to create 
marketing campaigns in order to communicate with customers. CRM technology allows employees to have necessary information before they make contact with customer. However, CRM technology is considered as expensive and complex innovation. It requires integrated information systems, costly infrastructure and advanced technological skills. The price paid by bank for purchase of CRM technology depends on volume of business (usually number of customers) and existing infrastructure. If bank is technologically mature; employees have a significant level of technological knowledge; CRM technology make advantage compared to other banks, so benefit of adopting CRM concept must be higher (9).

\section{Customer Retention}

Customer retention consist of steps taken by a selling organization in order to reduce customer defection and successful customer retention starts with the first contact an organization has with a customer and continues throughout the entire lifetime of a relationship (11). Also customer retention is important to most companies because the cost of acquiring a new customer is far greater than the cost of maintaining a relationship with a current customer (12).

Also, in a study of application of porter's five forces framework in the banking industry of Tanzania, investigated porters five forces to 22 fully Fledged banks, 5 Regional Unit Banks, 5 Financial Institutions and 102 Bureau de Change and concluded that there is high bargaining power of customers and also barriers to entry are gentle there by allowing more entrants to get in to the industry. Since customers have a high bargaining power and entrance is gentle, it is of vital importance for the banks to make sure that they have a customer retention strategy in place (13). This study therefore hypothesized that;

\section{Hı: Organizational structure positively and significantly impact on customer retention.}

The researchers are also of the view that organisational structure does not on its own lead to customer retention, but can be affected by communication channels. In this regard, the study hypothesized that;

\section{H2: Communication channels positively and negatively impact on customer retention.}

\section{Communication in the Banking Sector}

Communication between customers and banks is built in a form of two-way dialogue; hence business success is measured by participation of customers in communication. Banks are developing direct banking channels, which allow customers faster andeasier banking operations (9).

\section{Organisational Structureand Customer Retention}

Success of bank in today`s competitive environment, depends on ability of top management to adjust business environment where employees manage business processes and implement business relationships with customers. Banks often seek for employees who have appropriate leadership (8). Top management should be actively involved in changes in organization in order to spread positive vision of CRM concept and to support organizational change.

Customers on several occasions complain on issue of quality, implying that banks have not been able to meet what they promise (14). This has led to an increasing trend in customer switching between bank branches and one bank to another, which signals that the particular branches and banks have failed to meet customer expectations (14). These study points to the fact that technology availability affects customer retention. Hence, the study has hypothesized that:

\section{H3: Technology Availability affects Customer Retention.}


Effect of Customer Relationship Management on Customer Retention in the Ghanaian Banking Sector

\section{Methodology And Measurement of Construct}

\section{Methodology}

This study is an applied research in terms of its objectives, it is quantitative in terms of data collection and analysis, and it is explanatory research design to establish causal relationships among customer relationship management, organisational structure, communication channels, technology availability and customer retention. The statistical community of this study consists of customers of both public and private banks in the Ashanti Region of Ghana. Samples of 278 were selected from the Santasi area within the region. (15) has stated that, as small as of 30 samples is enough for successful statistical study if the characteristics of the respondents are homogenous in nature hence a sample of 278 is more than enough to be a representative of customers of various financial institutions. Convenient and purposive sampling techniques were adopted in selecting respondent. The study used questionnaires in collecting primary data from respondents. The questionnaires were closed ended on a 7-point Likert scale ranging from strongly disagree [1] to strongly agree [5] to the statements on the questionnaires. The researchers employed 2 additional field personnel who were trained to assist in data collection after the pilot testing was done. The study made use of IBM Statistical Package for Social Science (SPSS) version 20 in conducting the analysis.

\section{Measurement of Constructs}

Measurement of Construct

\begin{tabular}{|c|c|c|}
\hline & VARIABLES & SOURCES \\
\hline $\begin{array}{l}\text { Customer Relationship } \\
\text { Management (CRM) }\end{array}$ & $\begin{array}{l}\text { Organisational structure } \\
\text { Communication structure } \\
\text { Technology availability } \\
\text { Resisting customer complaints }\end{array}$ & $\begin{array}{l}\text { (Day, 2003) } \\
\text { (Laketa, Sanader, Misic and Laketa, 2015) and } \\
\text { (Mols, 1999) } \\
\text { (Laketa, Sanader, Misic and Laketa, 2015) } \\
\text { (Uppal, 2007) }\end{array}$ \\
\hline Customer Retention & $\begin{array}{l}\text { Service quality } \\
\text { Satisfaction }\end{array}$ & $\begin{array}{l}\text { (Kassim, } 2001 \text { \&Bloemeret al., 1998) } \\
\text { (Murphy 1997, Bloemer, Ruyter and Peeters } \\
\text { 1998) } \\
\text { (Bloemer, Ruyter and Peeters, 1998). }\end{array}$ \\
\hline Customer Satisfaction & Expectation & $\begin{array}{l}\text { (Grönroos, 2008), (Pinder et al., 2003), (Johnson } \\
\text { et al., 2001) }\end{array}$ \\
\hline
\end{tabular}

Variability and Reliability Assessment

The clarity of the instrument items to the respondents was established so as to enhance the instrument's validity and reliability. Validity is the degree by which the sample of test items represents the content the test is designed to measure (16). To establish the validity of the research instrument the research sought opinions of experts in the field of study especially the researcher's supervisor. Reliability refers to the consistency of measurement and is frequently assessed using the test-retest reliability method (17). Reliability was tested using Cronbach Alpha test with a threshold of 0.7 . This facilitated the necessary revision and modification of the research instrument.

American Research Journal of Business and Management 
Effect of Customer Relationship Management on Customer Retention in the Ghanaian Banking Sector Reliability of data using Cronbach alpha

\begin{tabular}{|l|l|l|}
\hline Variables & Cronbach alpha value & Number of items \\
\hline Organisational structure & 0.760 & 6 \\
\hline Communication channel & 0.727 & 6 \\
\hline Technology availability & 0.835 & 6 \\
\hline Resisting customer complaints & 0.778 & 6 \\
\hline Perceived performance & 0.755 & 6 \\
\hline Expectation & 0.847 & 6 \\
\hline Customer retention & 0.878 & 6 \\
\hline
\end{tabular}

Source: Researchers Field Work 2018

\section{Reliability of Data Using Cronbach Alpha}

The study reliability is based on the various scales and the variables used were assessed using Cronbach alpha coefficient. In conducting the study, a wide range of scales were included, hence, checking the how well these scales produce results that are good enough for analysis is very paramount. The motive for assessing the reliability is to be sure of how consistent the items used to define the variables are. In checking the reliability the scales, the Cronbach alpha was used. However, researchers postulate that, for scale reliability, Cronbach alpha value should be 0.7 and more (18). Cronbach alpha coefficient should be above 0.7 . Cronbach alpha values above 0.7 are acceptable and values that are above 0.8 are preferable (19). In checking the reliability for the scales used in the study, the results showed Cronbach values of $0.760,0.727,0.835,0.778,0.755,0.847$ and 0.878 for organisational structure, communication channel, and technology availability, resisting customer complaints, perceived performance, expectation and customer retention respectively. Cronbach alpha coefficient for the variables present that the scales used were reliable and items contains in them appropriately measures the underlying variables. The table below presents the reliability results of the scales.

\section{Pearson Correlation Analysis}

Table4.3. Correlations

\begin{tabular}{|l|l|l|l|l|}
\hline & ORGSTRT & COM.CHANNL & TECH.AVLBLTY & PERC.PERFMNCE \\
\hline ORGSTRT & 1278 & & & \\
\hline COM.CHANNL & 0.582 & 1278 & & \\
\hline TECH.AVLBLT & 0.658 & 0.650 & 1 & \\
\hline PERC.PERFMNCE & 0.564 & 0.453 & 0.571 & 1 \\
\hline
\end{tabular}

**. Correlation is significant at the 0.01 level (2-tailed).

Key: RESST.CUST.COMPLNT = Resisting Customer Complaint; COM.CHNNEL= Communication Channel

ORGSTRT= Organizational structure; TECH.AVLBLTY= Technology Availability

\section{Correlation Matrix}

The Pearson correlation was also run to test the relationship that existed between the variables used in the study and to also help the study to assess if there is a multicolloneality among the variables used for the study.

In quantitative research the concept of correlation is one of the techniques invariably used to assess whether there is a relationship between two or more variables. Statisticians have developed and used statistical tools which enable them make statistical analysis about the relationship variables. Thus, to check the extent to which 
a variable is account for by another variable. In order to check whether the strength of the relationship between the variables will affect further statistical analysis; a multicolloneality test was performed using the correlation statistics. For the method to be robust, it is suggested that the correlation statistics should not exceed 0.7 (20); (21). As shown in the table above.

\section{ANALYSIS AND DISCUSSION}

The study was conducted on a total of 278 bank customers within Kumasi out of which 278 responses were received representing 100\% response rate. The study made use of SPSS version 20 as software for analysis.

\section{Demographic Information}

Males were the dominant gender with $50.7 \%$ as compared to females with $49.3 \%$.

The age of respondents was grouped into five, respondents who are between Under 20, 21-30, 31-40, 41-50 and 51 and above. Respondents between the ages of 21-30 were dominant with 45.7\% followed by respondents between the age of 31-40 with 35.3\%; respondents between 41-50 with 10.4\%, respondents of 51 years and above as well as respondents under 20 equally had 4.3\%; making up the categories with least percentage.

Respondents who do business with private banks are dominant $62.6 \%$ whilst respondents who do business with public banks were least 37.4\%. Most of the respondents whose years of been customers between 1-5 had 50.7\%; respondents between 6-10 had 38.1\%; respondents between 11-15 had 6.8\%; respondents between 16-20 had 4.0\% whilst respondents above 21 had the least percentage with $0.4 \%$. This indicates that most of the respondents have been a customer of the bank for not more than 5 years.

The study grouped respondents occupation into three namely; salaried, businessman and student. From the study respondents whose occupations fall within the Businessman category were dominant with 38.5\%, followed by students $33.8 \%$ and salaried making the least with $27.7 \%$.

The qualification of respondents were also categorised into three namely; graduates, masters and others. Thus graduates referring to those with first degree, masters referring to those with a second degree and others refer to any other qualification. The study revealed that dominant qualification was the graduate category with $51.4 \%$ whilst the masters had $19.8 \%$ and others had $28.8 \%$.

Table4.1. Demographic information

\begin{tabular}{|l|l|l|l|}
\hline & Variables & Frequency & Percentage (\%) \\
\hline 1 & Type of Bank & & \\
\hline & Public & 104 & 37.4 \\
\hline & Private & 174 & 62.6 \\
\hline 2 & Number of years as a customer & & \\
\hline & $1-5$ & 141 & 50.7 \\
\hline & $6-10$ & 106 & 38.1 \\
\hline & $11-15$ & 19 & 6.8 \\
\hline & $16-20$ & 11 & 4.0 \\
\hline & Above 21 & 1 & 0.4 \\
\hline 3 & Occupation & & \\
\hline & Salaried & 77 & 27.7 \\
\hline & Businessman & 107 & 38.5 \\
\hline & Student & 94 & 33.8 \\
\hline
\end{tabular}


Effect of Customer Relationship Management on Customer Retention in the Ghanaian Banking Sector

\begin{tabular}{|l|l|l|l|}
\hline 4 & Qualification & & \\
\hline & Graduate & 143 & 51.4 \\
\hline & Masters & 55 & 19.8 \\
\hline & Others & 80 & 28.8 \\
\hline 5 & Age & & \\
\hline & $21-30$ & 127 & 45.7 \\
\hline & $31-40$ & 98 & 35.3 \\
\hline & $41-50$ & 29 & 10.4 \\
\hline & 51 and above & 12 & 4.3 \\
\hline 6 & Gender & & \\
\hline & Male & 141 & 50.7 \\
\hline & Female & 137 & 49.3 \\
\hline
\end{tabular}

Source: Author field work, 2018

To Evaluate Effects of Customer Relationship Management on Customer Retention in the Banking Sector.

To evaluate effects of customer relationship management on customer retention in the banking sector, the multiple regression analysis was conducted to investigate association between the predictor variables and then the criterion variable. Customer retention was defined as customers were satisfied with the services offered by their bank. The confidence level use was $95 \%$ with $5 \%$ margin of error. Thus, findings become statistically significant at 0.05 and below. Table 5.1, 5.2 and 5.3 show the model summary, ANOVA (Analysis of Variance) and the coefficient table from the regression output respectively.

Table5.1. Model Summary

\begin{tabular}{|l|l|l|l|l|}
\hline Model & $\mathrm{R}$ & R Square & Adjusted R Square & Std. Error of the Estimate \\
\hline 1 & $.733^{\mathrm{a}}$ & .537 & .530 & .56956 \\
\hline \multicolumn{2}{|l}{ a. Predictors: (Constant), RESST.CUST.COMPLNT, COM.CHANNL, ORGSTRT, TECH.AVLBLTY } \\
\hline
\end{tabular}

Key: RESST.CUST.COMPLNT= Resisting Customer Complaint; COM.CHNNEL= Communication Channel ORGSTRT= Organizational structure; TECH.AVLBLTY= Technology Availability

Table5.2. ANOVAb

\begin{tabular}{|l|l|l|l|l|l|l|}
\hline \multicolumn{2}{|l|}{ Model } & Sum of Squares & df & Mean Square & F & Sig. \\
\hline \multirow{3}{*}{1} & Regression & 102.666 & 4 & 25.667 & 79.122 & $.000^{\text {a }}$ \\
\cline { 2 - 7 } & Residual & 88.559 & 273 & .324 & & \\
\cline { 2 - 7 } & Total & 191.225 & 277 & & & \\
\hline \multicolumn{7}{|l|}{ a. Predictors: (Constant), RESST.CUST.COMPLNT, COM.CHANNL, ORGSTRT, TECH.AVLBLTY } \\
\hline
\end{tabular}

Key: RESST.CUST.COMPLNT = Resisting Customer Complaint; COM.CHNNEL= Communication Channel

ORGSTRT = Organizational structure; TECH.AVLBLTY= Technology Availability 
Effect of Customer Relationship Management on Customer Retention in the Ghanaian Banking Sector

Table5.3. Coefficientsa

\begin{tabular}{|c|c|c|c|c|c|c|}
\hline \multicolumn{2}{|c|}{ Model } & \multicolumn{2}{|c|}{ Unstandardized Coefficients } & \multirow{2}{*}{$\begin{array}{l}\text { Standardized } \\
\text { Coefficients } \\
\text { Beta }\end{array}$} & \multirow[t]{2}{*}{$\mathrm{t}$} & \multirow[t]{2}{*}{ Sig. } \\
\hline & & B & Std. Error & & & \\
\hline \multirow[t]{5}{*}{1} & (Constant) & .351 & .212 & & 1.655 & .099 \\
\hline & ORGSTRT & .125 & .075 & .098 & 1.662 & .098 \\
\hline & COM.CHANNL & -.053 & .069 & -.043 & -.766 & .444 \\
\hline & TECH.AVLBLTY & .246 & .070 & .233 & 3.499 & .001 \\
\hline & RESST.CUST.COMPLNT & .593 & .066 & .512 & 8.937 & .000 \\
\hline \multicolumn{3}{|c|}{ a. Dependent Variable: CUST.RETNTN } & & & & \\
\hline
\end{tabular}

Key: RESST.CUST.COMPLNT= Resisting Customer Complaint; COM.CHNNEL= Communication Channel

ORGSTRT= Organizational structure; TECH.AVLBLTY= Technology Availability

CUST.RETNTN= Customer Retention

\section{Regression Equation}

In assessing the relationship between customer relationship management and customer retention, the multiple regression analysis was conducted to check the nature and magnitude of the relationship between the independent variable and dependent variable. The regressions equation was therefore $\mathrm{y}=\mathrm{a}+\mathrm{b} 1 \mathrm{X} \mathrm{l}+\mathrm{b} 2 \mathrm{X} 2$ $+\mathrm{b} 3 \mathrm{X} 3+\mathrm{b} 4 \mathrm{X} 4$. When the figures from the output are estimated, the equation becomes $\mathrm{y}=0.351+0.125\left(\mathrm{X}_{\mathrm{l}}\right)-$ $0.053(\mathrm{X} 2)+0.246(\mathrm{X} 3)+0.593(\mathrm{X} 4)$

From the regression output, the results show that there is a strong relationship between customer relationship management and customer retention with a value of $0.733^{\circ}$. The R square value indicates that $53.7 \%(0.537)$ of the customers retained could be accounted for by the effort bank staff put in customer relationship management. From the ANOVA result, it shows that, the combined effect of resisting customer complaints, communication channel, organisational structure and technology availability is statistically significant ( $\left.F=79.122 ; p=000^{\mathrm{a}}\right)$. An F-statistics of 4 shows that the model is fit and therefore a value of 79.122 indicate the model is fit.

\section{Coefficient, Significance of the Model and Beta}

The regression result shows that, the coefficient value for organisational structure 0.125 showing positive relationship with customer retention. This means, all things being equal, when the other independent variables (resisting customer complaints, communication channel and technology availability) are held constant, customer retention will increase. Organisational structure is statistically not significant and is not making any contribution to the prediction of customer retention with $t$ value of 1.662 and significant at 0.098 . The implication is that, the organisational structure of banks does not matter to bank customers and hence does not contribute to their retention.

\section{Significance of Customer Relationship Management on Customer Retention}

Customer retention involves steps taken by a selling organization in order to reduce customer defection and successful customer retention starts with the first contact an organization has with a customer and continues throughout the entire lifetime of a relationship (11). Also customer retention is important to most companies 
because the cost of acquiring a new customer is far greater than the cost of maintaining a relationship with a current customer (12).

Moreover, in a study of application of porter's five forces framework in the banking industry of Tanzania, investigated porters five forces to 22 fully Fledged banks, 5 Regional Unit Banks, 5 Financial Institutions and 102 Bureau de Change and concluded that there is high bargaining power of customers and also barriers to entry are gentle thereby allowing more entrants to get in to the industry. Since customers have a high bargaining power and entrance is gentle, it is imperative for the banks to make sure that they have a customer retention strategy in place (13).

\section{CONCLUSION AND RECOMMENDATIONS}

The study reveals that customer satisfaction plays an important role in determining how various banks in the Kumasi metropolis are able to retain their customers. For organizations to continue staying in business, there is the need create a link or tie with the customers through the satisfaction of customers' needs. For developing customer satisfaction, reliability in the provision of services and commitment to service relationships is a must if a company must attempt to increase customer's future expectations.

CRM as a strategy aims to satisfy and build long term relationship with clients/customers. Through CRM customers were much satisfied with their purchase and this strategy helps to generate sales by contributing good service quality as expected by the customers.

The following recommendations are worth implementing based on the findings of the study

- Banks must make customer satisfaction their priority; customers are capable of increasing banks return on investment because when customers are satisfied they are encouraged to continue to do business with their financial organization.

- Customer relationship management should also be improved by various banks because it is through CRM that customers are satisfied; satisfied customers are easily retained.

- It must be the fundamental aim of firms to seek to manage and increase customer satisfaction at least in this era of competitive global marketing.

- The continuity of the business relations between the customer and organization depends on the relationship between the two parties hence banks must build effective communication channels.

- Success of bank in today`s competitive environment, depends on ability of top management to adjust business environment where employees manage business processes and implement business relationships with customers, hence banks must often seek for employees who have appropriate leadership.

- To remain competitive, companies must listen and respond to their customers' needs and expectations.

- Bank should select those channels that correspond to particular customer segments or individual customers.

- Selling organization need to reduce customer defection because successful customer retention starts with the first contact an organization has with a customer and continues throughout the entire lifetime of a relationship. 
- In acquiring customers, it is essential for organization to choose the right customers to serve before decide how they can best acquire them. This is particularly important as it is a fact that organization will not be able to serve all customers in every way.

- Customer satisfaction and customer perceptions of service quality were important predictors of loyalty in retail banking services hence financial institutions must work on positioning themselves well in the minds of their customers.

\section{REFERENCE}

1. Buttle F. Customer Relationship Management: Concepts and Technology. Sydney: a Butterworth-Heinemann Title; 2009.

2. Armstrong G, Kotler P, Merino MdJ, Pintado T, Juan J. Introducción al marketing: Pearson; 2011.

3. Jyh-Fu Jeng D, Bailey T. Assessing customer retention strategies in mobile telecommunications: Hybrid MCDM approach. Management Decision. 2012;50(9):1570-95.

4. Rahimi R, Kozak M. Impact of customer relationship management on customer satisfaction: The case of a budget hotel chain. Journal of Travel \& Tourism Marketing. 2017;34(1):40-51.

5. Blattberg RC, Getz G, Thomas JS. Customer equity. Harvard Business School Press, Boston. 2001.

6. Payne A. Customer retention. Marketing management: A relationship marketing perspective. 2000:110-9.

7. Shaw R. CRM definitions-Defining customer relationship marketing and management. Customer Relationship Management: Springer; 1999. p. 23-7.

8. Day GS. Creating a superior customer-relating capability. MIT Sloan Management Review. 2003;44(3):77.

9. Laketa M, Sanader D, Laketa L, Misic Z. Customer relationship management: concept and importance for banking sector. UTMS Journal of Economics. 2015;6(2):241.

10. Mols NP, Nikolaj D. Bukh P, Flohr Nielsen J. Distribution channel strategies in Danish retail banking. International Journal of Retail \& Distribution Management. 1999;27(1):37-47.

11. Flavian C, Torres E, Guinaliu M. Corporate image measurement: A further problem for the tangibilization of Internet banking services. International Journal of Bank Marketing. 2004;22(5):366-84.

12. Craddock RC, James GA, Holtzheimer PE, Hu XP, Mayberg HS. A whole brain fMRI atlas generated via spatially constrained spectral clustering. Human brain mapping. 2012;33(8):1914-28.

13. Eboli L, Mazzulla G. A new customer satisfaction index for evaluating transit service quality. Journal of Public transportation. 2009;12(3):2.

14. Lwiza DR, Nwankwo S. Market-driven transformation of the banking sector in Tanzania. International Journal of Bank Marketing. 2002;20(1):38-49.

15. Stutely R. Numbers guide: Bloomberg Press; 2003.

16. Sekaran U. Research methods for business. Ed. Ke-4. USA: John Wiley \& Sons. Inc; 2003.

17. Mark S, Philip L, Adrian T. Research methods for business students. Prentice Hall; 2009. 
Effect of Customer Relationship Management on Customer Retention in the Ghanaian Banking Sector

18. Cresswell J, Plano-Clark V. Choosing a mixed methods study design. Designing and conducting mixed methods research. 2007:58-88.

19. DeVellis RF. Scale development: Theory and applications. Applied social research methods series. Bickman, L and DJ Rog. Thousand Oaks, Calif.: SAGE Publications, Inc; 2003.

20. F. Hair Jr J, Sarstedt M, Hopkins L, G. Kuppelwieser V. Partial least squares structural equation modeling (PLS-SEM) An emerging tool in business research. European Business Review. 2014;26(2):106-21.

21. Pallant J. SPSS survival manual, 3rd. Edition McGrath Hill. 2007.

Citation: Jerry Jay Kraa, Bismark Adanse Bonna, Aquila Hannah, Kankam Boadu. "Effect of Customer Relationship Management on Customer Retention in the Ghanaian Banking Sector" American Research Journal of Business and Management. 2018; 4(1): 1-12.

Copyright (c) 2018 Jerry Jay Kraa, Bismark Adanse Bonna, Aquila Hannah, Kankam Boadu. This is an open access article distributed under the Creative Commons Attribution License, which permits unrestricted use, distribution, and reproduction in any medium, provided the original work is properly cited. 